\title{
The International Reference Ionosphere: Rawer's IRI and its status today
}

\author{
D. Bilitza ${ }^{1,2}$ \\ ${ }^{1}$ Space Weather Laboratory, George Mason University, Fairfax, Virginia, USA \\ ${ }^{2}$ Heliospheric Physics Laboratory, NASA Goddard Space Flight Center, Greenbelt, Maryland, USA \\ Correspondence to: D. Bilitza (dbilitza@gmu.edu)
}

Received: 3 February 2014 - Accepted: 20 March 2014 - Published: 10 November 2014

\begin{abstract}
When the Committee on Space Research (COSPAR) initiated the International Reference Ionosphere (IRI) project in 1968 it wisely selected K. Rawer as its first Chairperson. With a solid footing and good contacts in both the ground-based and space-based ionospheric communities he was ideally suited to pull together colleagues and data from both communities to help build the first version of the IRI. He assembled a team of $20+$ international ionospheric experts in the IRI Working Group and chaired and directed the group from 1968 to 1984 . The working group has now grown to 63 members and the IRI model has undergone many revisions as new data became available and new modeling techniques were applied. This paper was presented during a special session of the Kleinheubach Tagung 2013 in honor of K. Rawer's 100th birthday. It will review the current status of the IRI model and project and the international recognition it has achieved. It is quite fitting that this year we not only celebrate K. Rawer's 100th birthday but also the exciting news that his favorite science endeavor, IRI, has been internationally recognized as an ISO (International Standardization Organization) standard. The IRI homepage is at http://irimodel.org.
\end{abstract}

\section{Introduction}

The International Reference Ionosphere (IRI) is a joint project of the Committee on Space Research (COSPAR) and the International Union of Radio Science (URSI) with its goals well described in its Terms of Reference as follows: "The Task Group was established to develop and improve a standard model of the ionospheric plasma parameters. The model should be primarily based on experimental evidence using all available ground and space data sources; theoretical considerations can be helpful in bridging data gaps and for internal consistency checks. Where discrepancies exist between different data sources the IRI team should promote critical discussion to establish the reliability of the different databases. IRI should be updated as new data become available and as old data sources are fully evaluated and exploited. IRI is a joint working group of COSPAR and URSI. COSPAR's prime interest is in a general description of the ionosphere as part of the terrestrial environment for the evaluation of environmental effects on spacecraft and experiments in space. URSI's prime interest is in the electron density part of IRI for defining the background ionosphere for radiowave propagation studies and applications." When COSPAR initiated the International Reference Ionosphere (IRI) project in 1968 it wisely selected K. Rawer as its first Chairperson. With a solid footing and good contacts in both the ground-based and space-based ionospheric communities he was ideally suited to pull together colleagues and data from both communities to help build the first version of the model. He also succeeded to get URSI to concur in the project and thus making IRI a joint project of the prime international unions involved in ionospheric physics. He convinced $20+$ international ionospheric experts to join him in the IRI Working Group and chaired and directed the group from 1968 to 1984. In assembling the working group he made sure to get a good representation of nations involved in ionospheric research and a good representation of the different measurement techniques used to observe the ionosphere. The working group has now grown to 63 members. The current roster is listed in Table 1.

IRI is a data-based (empirical) model of monthly averages of ionospheric parameters in the altitude range $50-2000 \mathrm{~km}$. 
Table 1. IRI Working Group Members and Steering Committee.

\begin{tabular}{|c|c|}
\hline \multicolumn{2}{|l|}{ Steering Committee: } \\
\hline $\begin{array}{l}\text { L.-A. McKinnell (South Africa) Chair } \\
\text { V. Truhlik (Czech Rep.) URSI Vice-Chair, S. Watanabe (Japan) COSPAR Vice-Chair } \\
\text { D. Bilitza (USA), Executive Secretary, B. Reinisch (USA), Editor }\end{array}$ & \\
\hline \multicolumn{2}{|l|}{ Members by Country: } \\
\hline $\begin{array}{l}\text { ARGENTINA: M. Mosert de Gonzalez, R. Ezquer } \\
\text { AUSTRIA: M. Friedrich BRAZIL: M. Abdu } \\
\text { CHINA: Jiankui Shi, W. Wan, M.-L. Zhang } \\
\text { CZECH REP: D. Buresova, L. Triskova, V. Truhlik } \\
\text { GERMANY: W. Singer, C. Stolle } \\
\text { INDIA: K. Mahajan, S. Gupta, P.K. Bhuyan } \\
\text { JAPAN: K. Oyama, K. Igarashi, S. Watanabe } \\
\text { POLAND: I. Stanislawska, A. Krankowski, H. Rothkaehl } \\
\text { RUSSIA: A. Danilov, V. K. Depuev, T. Gulyaeva, G. Ivanov-Kholodny, A. Mikhailov, } \\
\text { S. Pulinets, K.G. Ratovsky, I. Zakharenkova } \\
\text { SOUTH AFRICA: A. Poole, L.-A. McKinnell } \\
\text { SPAIN: D. Altadill } \\
\text { U.K.: P. Bradley, L.R. Cander, M. Rycroft } \\
\text { USA: D. Anderson, E. Araujo-Pradere, D. Bilitza, M. Codrescu, T. Fuller-Rowell, X. Huang, } \\
\text { C. Mertens, B. Reinisch, L. Scherliess, J. Sojka, V. Wickwar, S-R. Zhang, I. Galkin }\end{array}$ & $\begin{array}{l}\text { AUSTRALIA: B. Ward, P. Wilkinson } \\
\text { BULGARIA: I. Kutiev } \\
\text { FRANCE: D. Alcayde, R. Hanbaba } \\
\text { GREECE: S. Kouris } \\
\text { IVORY COAST: O. Obrou } \\
\text { ITALY: S. Radicella, B. Zolesi } \\
\text { NIGERIA: J. Adeniyi, E. Oyeyemi } \\
\text { R.O.C.: S.-Y. Su }\end{array}$ \\
\hline \multicolumn{2}{|l|}{ Former Members: } \\
\hline $\begin{array}{l}\text { K. Bibl (USA), L. Bossy (Belgium) [IRI Chair from } 1984 \text { to 1992], L.H. Brace (USA), K. Champion (USA), } \\
\text { Y. Chasovitin (Russia), P. Dyson (Australia), W. Hoegy (USA), } \\
\text { E. Kazimirovsky (Russia), E. Kopp (Switzerland), T. Maruyama (Japan), N. Matuura (Japan), } \\
\text { A.P Mitra (India), K. Rawer (Germany) [IRI Chair from } 1968 \text { to 1984], K. Serafimov (Bulgaria) }\end{array}$ & \\
\hline
\end{tabular}

Parameters include the electron density, electron temperature, ion composition (percentage of $\mathrm{O}^{+}, \mathrm{H}^{+}, \mathrm{He}^{+}, \mathrm{N}^{+}$, $\mathrm{NO}^{+}, \mathrm{O}_{2}^{+}$, and Cluster ions), ion temperature, ionospheric electron content up to a specified upper height limit, ion drift at magnetic equator, spread-F occurrence probability, and auroral boundaries. These parameters are given as functions of height, latitude, longitude, time of day (LT or UT), and date. Required model drivers are solar indices (13 month running mean of sunspot number; daily, yearly, and 81 day averages of the solar radio flux at $10.7 \mathrm{~cm}$ wavelength), ionospheric index (13 months running mean of Global Ionosphere index IG), magnetic indices (daily and $3 \mathrm{~h}$ ap), COSPAR International Reference Atmosphere (CIRA) neutral densities and temperature, and optional measured values for the peak plasma frequencies foF2, foF1, foE, foD (or peak densities $\mathrm{NmF} 2, \mathrm{NmF} 1, \mathrm{NmE}, \mathrm{NmD}$ ) and/or peak heights hmF2 (or the correlated propagation factor $\mathrm{M}(3000) \mathrm{F} 2), \mathrm{hmE}, \mathrm{hmD}$.

Bi-annual IRI workshops that were introduced by K. Rawer are the lifeblood of the IRI activity. They are the prime platform for the discussions of IRI shortcomings, improvements, and additions. The most recent workshop was held in Olsztyn, Poland in June of this year with a special focus on IRI and GNSS data. A wealth of information about the IRI project can be found on the IRI homepage at http://irimodel.org including information about past and future IRI workshops, IRI publications, and access to the model Fortran code and an interface for computing IRI parameters online. This paper briefly reviews the milestones of the IRI project and presents the latest version, IRI-2012, and some of recent accomplishments and acknowledgements.

\section{IRI milestones}

Rawer et al. (1975) published the first IRI as a set of tables of ionospheric parameters for a limited set of conditions. After this first release new version were presented in roughly a five year cycle always expanding the scope of the model based on an ever increasing underlying database (Rawer et al., 1978a, b, 1981; Bilitza, 1986, 1990, 1997, 2001; Bilitza and Reinisch, 2008; Bilitza et al., 2014). The most important improvements accompanying each new version are listed in Table 2 and are described in detail in the corresponding science papers. The latest version is IRI-2012 which will be briefly discussed in the next section. Milestones were also achieved in adapting the IRI code to the quickly evolving computer technology providing the IRI Fortran code first on magnetic tape, then on punched tape and cards, then on floppy disk, and lastly online. From early on the model was made publically available as open source software and was widely distributed. IRI is used for a wide range of application including background ionosphere for HF propagation studies and forecast, background ionosphere for testing tomographic and radio occultation approaches, ionospheric corrections for Earth observations from space and for radioastronomy from 
the ground, ionospheric parameters for theoretical models, and many more. Progress of the IRI project and some of these applications are described in a series of dedicated issues of Advances in Space Research (see IRI homepage).

\section{IRI-2012}

In this section we will briefly summarize the changes from IRI-2007 to IRI-2012. In the region below the F-peak new models for the electron density and ion composition have resulted in a $20-40 \%$ improvement. For the electron density this was achieved with the model of Altadill et al. (2009) for the bottomside thickness $B_{0}$ and the shape parameter $B_{1}$. Their model is based on a large volume of data from the worldwide network of ionosondes and describes variations with modified dip latitude, Local Time, month, and sunspot number. For the ion composition Richards et al. (2010) use the well-established photochemistry in the lower ionosphere as provided in the Field Line Interhemispheric Plasma (FLIP) physical model (Richards, 2001) to determine the densities of the major ions in this region. By normalizing the total ion density to the IRI electron density they determine the IRI ion composition. In comparisons with Atmosphere Explorer C data they could show that their model provides a more accurate description of the molecular ions than the old IRI-2007 ion composition model. In the topside ionosphere the work of Bilitza et al. (2007) and Truhlik et al. (2009) with a large volume of satellite in situ measurements has resulted in a better understanding of the solar cycle variations of electron temperature and in the inclusion of the this effect in the IRI electron temperature model (Truhlik et al., 2012). With this latest version IRI for the first time will include a representation of auroral oval boundaries based on the work of Zhang and Paxton (2008) with observations from the Global Ultraviolet Imager (GUVI) of the Thermosphere Ionosphere Mesosphere Energetics and Dynamics (TIMED) satellite. Data from another TIMED instrument, the Sounding of the Atmosphere using Broadband Emission Radiometry (SABER), proved to be a valuable asset in modeling storm effects in the auroral E-region. A model describing these effects was developed by Mertens et al. $(2013 \mathrm{a}, \mathrm{b})$ and is now included in IRI-2012. Finally, there are other significant updates that need to be mentioned. The MSIS-86 model for neutral densities and temperatures, used in earlier IRI versions, was replaced by the newer NRL-MSISE-00 model of Picone et al. (2002). Neutral densities and temperatures are needed for the ion composition model of Richards et al. (2010) and the neutral temperatures is required as to enforce thermal equilibrium $\left(T_{\mathrm{e}}=T_{\mathrm{i}}=T_{\mathrm{n}}\right)$ below $120 \mathrm{~km}$ and the condition $T_{\mathrm{e}} \geq T_{\mathrm{i}} \geq T_{\mathrm{n}}$ throughout the ionosphere. IRI-2012 applies the latest version of the International Geomagnetic Reference Field (IGRF) (Findlay et al., 2010) for the computation of magnetic coordinates. As a new magnetic coordinate system IRI-2012 now also includes the
Corrected Geomagnetic Coordinates (CGM) of Gustafsson et al. (1992).

\section{Measures of success}

Our honoree, K. Rawer, can be proud of his IRI that over the years has received a high degree of international recognition and has proven its reliability in many comparisons with data and models. We will list some of these achievements in this section. A 1999 URSI resolution recognized IRI as the internationally recommended model for the ionosphere (see Table 2). IRI was selected as the standard for the ionosphere by the European Cooperation for Space Standardization (ECSS, 2008) as well as the International Standardization Organization (ISO) (Gulyaeva and Bilitza, 2011). The wide scientific usage of the IRI model is documented by the large number of scientific publications that acknowledge the use of IRI. Table 3 shows the percentage of papers that used IRI in the years 2009 through 2012 in the science journals Journal of Geophysical Research (JGR) - Space, Geophysical Research Letters (GRL), Space Weather (SW) journal, and Radio Science (RS). The percentage of papers using IRI is increasing from year to year, reaching $8 \%$ for JGR, $9.5 \%$ for SW and an amazing $15 \%$ for RS in 2012; so every 7th RS paper in 2012 relied on IRI to achieve its science goals. In addition to these four journals there are many other journals with articles that reference the usage of the IRI model. A wider literature search reveals 133 citations of the IRI-2007 paper (Bilitza and Reinisch, 2008) in 2011 and 138 citations in 2012 across a wide spectrum of journals, 23 in all, including, for example, GPS Solutions, Computer Physics Communications, Solar Physics, Applied Optics, Plasma Science and Technology, and Computers \& Geosciences. Finally, we can also record a remarkable increase in the number of accesses to the web interface for computing IRI parameters (IRIWeb at http:// omniweb.gsfc.nasa.gov/vitmo/iri2012_vitmo.html) with accesses recently reaching the 1 million per month mark.

The IRI model has gained this high level of acceptance and trust because it has been extensively evaluated with large volumes of data from ground and space measurement techniques. When discrepancies were found, the IRI team made it its highest priority to improve the model to accurately represent the new data source. Recently the Coupling, Energetics, and Dynamics of Atmospheric Regions (CEDAR) program of the National Science Foundation (NSF) initiated the Electrodynamics Thermosphere Ionosphere (ETI) Challenge to assess the accuracy of ionosphere/thermosphere models in reproducing ionosphere and thermosphere parameters. A total of nine events and five physical parameters were selected to compare observations with the predictions by 10 of the most well established ionosphere/thermosphere models. IRI was the only data-based model, all others were physicsbased models and two of these in addition employed data assimilation techniques with GPS data for the respective event 
Table 2. IRI Milestones.

\begin{tabular}{|c|c|c|c|}
\hline Year & Event (Reference) & Description & Data Base \\
\hline 1968 & $\begin{array}{l}\text { COSPAR establishes } \\
\text { IRI Working Group }\end{array}$ & $\begin{array}{l}\text { K. Rawer, Chair; WG members pre- } \\
\text { dominantly from space community } \\
\text { (satellite and rocket measurements) }\end{array}$ & \\
\hline 1969 & URSI joins IRI project & $\begin{array}{l}\text { New WG members from ground obser- } \\
\text { vation community }\end{array}$ & \\
\hline 1975 & $\begin{array}{l}\text { IRI-75: Set of Tables (Rawer et } \\
\text { al., 1975) }\end{array}$ & $\begin{array}{l}\text { Representative values for equat., low, } \\
\text { mid latitudes }\end{array}$ & Ionosonde, ICS, AEROS \\
\hline 1978 & $\begin{array}{l}\text { IRI-79: URSI Special Rep. } \\
\text { (Rawer et al., 1978a,b) }\end{array}$ & $\begin{array}{l}\text { Global coverage using CCIR maps for } \\
\text { peak parameters, modified for foF1 and } \\
\text { foE; } \\
\text { using IG12 with foF2 }\end{array}$ & Global ionosonde network \\
\hline 1981 & $\begin{array}{l}\text { IRI-79: WDC-A-STP Rep. } \\
\text { (Rawer et al., 1981) }\end{array}$ & & \\
\hline 1986 & $\begin{array}{l}\text { IRI-86: floppy disk for PC } \\
\text { (Bilitza, 1985, 1986) }\end{array}$ & $\begin{array}{l}\text { - Improved Ne at low latitudes } \\
\text { - Global Te, Ti models }\end{array}$ & $\begin{array}{l}\text { AEROS-A,-B, AE-C,-D,-E, } \\
\text { ISIS-1, -2, ICS data }\end{array}$ \\
\hline 1990 & $\begin{array}{l}\text { IRI-90: NSSDC Report } \\
\text { (Bilitza, 1990) }\end{array}$ & $\begin{array}{l}\text { - URSI maps for } f o F 2 \\
\text { - Improved NmE model }\end{array}$ & $\begin{array}{l}\text { - More global ionosonde data } \\
\text { - Incoherent scatter (ICS) data }\end{array}$ \\
\hline 1995 & $\begin{array}{l}\text { IRI-95: online (IRIWeb) } \\
\text { (Bilitza, 1997) }\end{array}$ & Improvements at low latitudes & DE-2 data \\
\hline 1999 & URSI Resolution & $\begin{array}{l}\text { IRI recognized as the international } \\
\text { standard for the ionosphere }\end{array}$ & \\
\hline 2001 & IRI-2001 (Bilitza, 2001) & $\begin{array}{l}\text { - } 2 \text { new options for Ne D-region } \\
\text { - new models for F1 and B0,B1 } \\
\text { - STORM model } \\
\text { - New model for Te }\end{array}$ & $\begin{array}{l}\text { - Rocket compilations } \\
\text { - Ionsonde network } \\
\text { - Stormtime ionosonde data } \\
\text { - Intercosmos } 19,24,25\end{array}$ \\
\hline 2007 & $\begin{array}{l}\text { IRI-2007 (Bilitza and Reinisch, } \\
\text { 2008) }\end{array}$ & $\begin{array}{l}-2 \text { new options for Ne topside } \\
- \text { new ion composition model } \\
\text { - spread-F occurrence model }\end{array}$ & $\begin{array}{l}\text { - TS: Alouette 1,2, ISIS } 1,2 \\
\text { - AE-C,-E, Intercosmos } 24 \\
\text { - Brazilian ionosonde data }\end{array}$ \\
\hline 2012 & IRI-2012 (Bilitza et al., 2014) & See Sect. 3. & \\
\hline
\end{tabular}

Table 3. Percentage of JGR, GRL, SW, and RS papers acknowledging IRI usage.

\begin{tabular}{rrrrr}
\hline Year & $\begin{array}{r}\text { J. Geophys. } \\
\text { Res. }\end{array}$ & $\begin{array}{r}\text { Geophys. } \\
\text { Res. Lett. }\end{array}$ & $\begin{array}{r}\text { Space } \\
\text { Weather }\end{array}$ & $\begin{array}{r}\text { Radio } \\
\text { Sci. }\end{array}$ \\
\hline 2009 & $5.0 \%$ & $3.6 \%$ & $0.0 \%$ & $10.5 \%$ \\
2010 & $5.6 \%$ & $4.7 \%$ & $5.6 \%$ & $11.8 \%$ \\
2011 & $7.1 \%$ & $1.6 \%$ & $8.1 \%$ & $14.2 \%$ \\
2012 & $8.0 \%$ & $1.7 \%$ & $9.5 \%$ & $15.1 \%$ \\
\hline
\end{tabular}

periods. IRI performed very well in this challenge and was best or one of the three best in all categories considered by this challenge (Shim et al., 2011, 2012). It is noteworthy that in several cases IRI performed better than the physics-based models with data assimilation capabilities.

\section{Conclusions}

Empirical models play an important role in all parts of the Sun-Earth environment. They give the scientist, engineer, and educator easy access to a condensed form of the available empirical evidence for a specific parameter, optimally, being based on all reliable data sources that exist for the parameter. Examples of such widely used models are the International Geomagnetic Reference Field (IGRF) model for Earth's magnetic field (Finlay et al., 2010) and the Mass Spectrometer and Incoherent Scatter (MSIS) model for Earth's Atmosphere (Picone et al., 2002). The ionospheric equivalent to these models is the model that was initiated by $\mathrm{K}$. Rawer and that has matured into the recognized international standard for the Earth's ionosphere. Many of the special ingredients that made the IRI such a success story were initiated by K. Rawer including: (1) A working group roster 
that provides a good, balanced cross-section in terms of the represented countries and the represented measurement techniques. This turned out to be a great asset in gaining access to essentially all reliable ground and space data sets for ionospheric parameters. (2) Bi-annual IRI Workshops that are the main venue for discussing improvements and enhancements to the model. A trademark of these informal meetings is the "Final Discussion" session where the IRI team decides on the improvements and additions to be included in the next version of the model. (3) A user-friendly open source software in which new models are included as options to be evaluated and tested by the wide IRI user community.

I want to conclude by sending a heartfelt "Thank You" on behalf of the whole IRI team to our honoree K. Rawer whose foresightedness made IRI into the great success that it is today.

Edited by: M. Förster

Reviewed by: L. R. Cander and one anonymous referee

\section{References}

Altadill, D., Torta, J. M., and Blanch, E.: Proposal of new models of the bottom-side B0 and B1 parameters for IRI, Adv. Space Res., 43, 1825-1834, doi:10.1016/j.asr.2008.08.014, 2009.

Bilitza, D.: International Reference Ionosphere: Recent Developments, Radio Sci., 21, 343-346, doi:10.1029/RS021i003p00343, 1986.

Bilitza, D.: International Reference Ionosphere 1990, National Space Science Data Center, Report 90-22, Greenbelt, Maryland, USA, 1990.

Bilitza, D.: International Reference ionosphere - Status 1995/96, Adv. Space Res., 20, 1751-1754, 1997.

Bilitza, D.: International Reference Ionosphere 2000, Radio Sci., 36, 261-275, doi:10.1029/2000RS002432, 2001.

Bilitza, D. and Reinisch, B. W.: International Reference Ionosphere 2007: Improvements and new parameters, Adv. Space Res., 42, 599-609, doi:10.1016/j.asr.2007.07.048, 2008.

Bilitza, D., Truhlik, V., Richards, P., Abe, T., and Triskova, L.: solar cycle variation of mid-latitude electron density and temperature: Satellite measurements and model calculations, Adv. Space Res., 39, 779-789, doi:10.1016/j.asr.2006.11.022, 2007.

Bilitza, D., Altadill, D., Zhang, Y., Mertens, C., Truhlik, V., Richards, P., McKinnell, L.-A., and Reinisch, B.: The International Reference Ionosphere 2012 - A Model of International Collaboration, J. Space Weather Space Clim., 4, 1-12, doi:10.1051/swsc/2014004, 2014.

ECSS, European Cooperation for Space Standardization, System Engineering: Space Environment, ECSS-E-ST-10-04C, Noordwijk, the Netherlands, 2008.

Finlay, C. C., Maus, S., Beggan, C. D., Bondar, T. N., Chambodut, A., Chernova, T. A., Chulliat, A., Golovkov, V. P., Hamilton, B., Hamoudi, M., Holme, R., Hulot, G., Kuang, W., Langlais, B., Lesur, V., Lowes, F. J., Lühr, H., Macmillan, S., Mandea, M., McLean, S., Manoj, C., Menvielle, M., Michaelis, I., Olsen, N., Rauberg, J., Rother, M., Sabaka, T. J., Tangborn, A., TøffnerClausen, L., Thébault, E., Thomson, A. W. P., Wardinski, I.,
Wei, Z., and Zvereva, T. I.: International Geomagnetic Reference Field: the eleventh generation, Geophys. J. Int., 18, 1216-1230, doi:10.1111/j.1365-246X.2010.04804.x, 2010.

Gulyaeva, T. and Bilitza, D.: Towards ISO Standard Earth Ionosphere and Plasmasphere Model, in: New Developments in the Standard Model, edited by: Larsen, R. J., Nova Science Publishers, Hauppauge, NY 11788-3619, USA, 2011.

Gustafsson, G., Papitashvili, N. E., and Papitashvili, V. O.: A Revised Corrected Geomagnetic Coordinate System for Epochs 1985 and 1990, J. Atmos. Terr. Phys., 54, 1609-1631, 1992.

Mertens, C. J., Xu, Xiaojing, Bilitza, D., Mlynczak, M. G., and Russell III, J. M.: Empirical STORM-E Model: I. Theoretical and Observational Basis, Adv. Space Res., 51, 554-574, doi:10.1016/j.asr.2012.09.009, 2013a.

Mertens, C. J., Xu, Xiaojing, Bilitza, D., Mlynczak, M. G., and Russell III, J. M.: Empirical STORM-E Model: II. Geomagnetic Corrections to Nighttime Ionospheric E-Region Electron Densities, Adv. Space Res., 51, 575-598, doi:10.1016/j.asr.2012.09.014, 2013b.

Picone, J. M., Hedin, A. E., Drob, D. P., and Aikin, A. C.: NRLMSISE-00 empirical model of the atmosphere: Statistical comparisons and scientific issues, J. Geophys. Res., 107, 1468, doi:10.1029/2002JA009430, 2002.

Rawer, K., Ramakrishnan, S., and Bilitza, D.: Preliminary reference profiles for electron and ion densities and temperatures proposed for the International Reference Ionosphere, Institut für physikalische Weltraumforschung, Scientific Report W.B. 2, Freiburg, Germany, 1975.

Rawer, K., Bilitza, D., and Ramakrishnan, S.: International Reference Ionosphere 1978, International Union of Radio Science (URSI), Brussels, Belgium, 1978a.

Rawer, K., Bilitza, D., and Ramakrishnan, S.: Goals and status of the International Reference Ionosphere, Rev. Geophys., 16, 177181, 1978b.

Rawer, K., Lincoln, V., and Conkright, R. (Eds.): International Reference Ionosphere - IRI 79, World Data Center A for SolarTerrestrial Physics, Report UAG-82, Boulder, Colorado, USA, 1981.

Richards, P. G.: Seasonal and solar cycle variations of the ionospheric peak electron density: comparison of measurement and models, J. Geophys. Res., 106, 12803-12819, doi:10.1029/2000JA000365, 2001.

Richards, P. G., Bilitza, D., and Voglozin, D.: Ion density calculator (IDC): A new efficient model of ionospheric ion densities, Radio Sci., 45, RS5007, doi:10.1029/2009RS004332, 2010.

Shim, J. S., Kuznetsova, M., Rastätter, L., Hesse, M., Bilitza, D., Codrescu, M., Emery, B., Foster, B., FullerRowell, T., Huba, J., Mannucci, A. J., Ridley, A., Scherliess, L., Schunk, R. W., Stephens, P., Thompson, D. C., Zhu, L., Anderson, D., Chau, J. L., Sojka, J. J., and Rideout, B.: CEDAR Electrodynamics Thermosphere Ionosphere 1 (ETI) Challenge for Systematic Assessment of Ionosphere/ Thermosphere Models 1: NmF2, hmF2, and Vertical Drift Using Ground Based Observations, Space Weather, 9, S12003, doi:10.1029/2011SW000727, 2011.

Shim, J. S., Kuznetsova, M., Rastätter, L., Hesse, M., Bilitza, D., Butala, M., Codrescu, M., Emery, B. A., Foster, B., FullerRowell, T. J., Huba, J., Mannucci, A. J., Pi, X., Ridley, A., Scherliess, L., Schunk, R. W., Sojka, J. J., Stephens, P., Thompson, D. C., Weimer, D., Zhu, L., and Sutton, E.: CEDAR Electrodynam- 
ics Thermosphere Ionosphere (ETI) Challenge for systematic assessment of ionosphere/thermosphere models: Electron density, neutral density, NmF2, and hmF2 using space based observations, Space Weather, 10, S10004, doi:10.1029/2012SW000851, 2012.

Truhlik, V., Bilitza, D., and Triskova, L.: Latitudinal variation of the topside electron temperature at different levels of solar activity, Adv. Space Res., 44, 693-700, doi:10.1016/j.asr.2009.04.029, 2009.
Truhlik, V., Bilitza, D., and Triskova, L.: A new global empirical model of the electron temperature with inclusion of the solar activity variations for IRI, Earth Planets Space, 64, 531-543, 2012.

Zhang, Y. and Paxton, L. J.: An empirical Kp-dependent global auroral model based on TIMED/GUVI data, J. Atmos. Sol.-Terr. Phy., 70, 1231-1242, doi:10.1016/j.jastp.2008.03.008, 2008. 